\title{
IRONBRIDGE - FROM MUSEUM TO WORLD HeRitage Site
}

\section{David de Haan}

Ironbridge wanted to be different. At the very earliest discussions way back in 1964, three years before the Museum Trust was formally set up, ideas had already been floated about radically rethinking what form a museum might take. The Gorge, although derelict, was recognised as being a potential cultural asset making the creation of a New Town possible. By 1964 the new town planners advised that "the industrial remains have significant national interest» and "it will become an important recreation area for the whole region... The north bank of the Severn might well be developed to provide the same facilities for recreation as Skansen." [Dawley New Town Draft Master Plan].

Two years later a Working Party proposed setting up an industrial trust, relying heavily on voluntary support and funded by industry and private or charitable sources. The idea of preserving the industrial buildings and monuments in situ was clearly set out, as was the idea of moving threatened buildings to an open air site. Most radical of all was the notion that the visitor might be prepared to pay for admission, at a time when virtually all museums in the country were free. While the natural beauty of the Gorge would provide a local amenity, the cultural heritage was recognised as being of wider interest.

\section{INTERPRETATION}

The Museum Trust was therefore set up to preserve and interpret the in-situ monu- ments of the Industrial Revolution in the Ironbridge Gorge, and where this was not possible, to consider moving them to an open air museum. The consequence of this is a multi-site museum which now takes about three days to see it all. Attitudes to museum interpretation have continued to change over the years, but with so many sites, there has been the scope to experiment with different approaches.

Museums in the 1960s had a bad name. They were seen as being dusty, boring, unfriendly, elitist and remote. At Ironbridge we tried to change that attitude, but it took time. At the beginning most displays were aimed at the mature, intelligent visitor. Guide books were full of long words with few illustrations because we believed we were telling the story of the Industrial Revolution to those 
42 who already knew about it, but who wanted details. Our exhibition graphics were textbooks on walls, all the same type size like a sea of grey, on the assumption that the visitor was hungry for detail and read everything. The content was excellent and the quality of presentation high because we believed from the outset that quality was what mattered. It looked good and it won us awards, but in terms of communication it was hard work.

In the first 10 years we were consciously trying to influence the decisionmakers by aiming at the top end of the market - the managerial and professional people who wanted their leisure time to be productive. Many of these early visitors also sat on the Boards of the Trust, Foundations and industries that we were approaching for funds, so the device was effective. This was not an Ecomuseum for the local community, but an attraction for visitors from much further afield, and as leisure time increased and the Gorge was restored from its derelict past into a place of beauty and pilgrimage, so the visitor market began to broaden.

Right from the beginning we started to experiment with demonstration, using techniques borrowed from America (especially Williamsburg and Sturbridge). When it first opened in March 1973, Blists Hill open air museum already had a demonstrator - a potter - who captured the visitors' interest. He was so good at it he hardly had any time to make pots, which was the main source of his income, and he left before he went bankrupt. But we had seen the magic and quickly developed a group of volunteer guides from the Friends of the Museum to work inside the reconstructed trade workshops and demon- strate the old processes of the nineteenth century. It became clear that this method of interpretation was popular with visitors and they came back time and again to see 'what was new since their last visit'.

Blists Hill was developing into a new type of museum. It had been conceived as a kind of open air park with re-erected monuments and buildings, but it rapidly evolved from this static approach into a dynamic museum which played heavily on interaction with visitors. Buildings were staffed at weekends by volunteers. The idea of costumed interpretation grew out of special events, e.g. a Victorian picnic when the Friends had been encouraged to come in costume. An exchange visit with staff of Sturbridge made it clear how effective costume could be, and in early 1979 the decision was taken that all demonstrators at Blists Hill should be in costume. We had settled, somewhat haphazardly, at 1895 as the date for our re-enactment, and as all the volunteers were dressed as shopkeepers or workers, the costume was everyday and not too unusual for the ultra-conservative British visitor. It was not until 1989 that the date was relaxed to 'turn of the century', being interpreted as 1900 plus or minus 10 years.

Volunteer demonstrators were virtually free but not necessarily reliable, and visitors were disappointed if any building was not manned. We found we had to provide a 7-day service, not just weekend demonstration, and with a period of government-supported employment programmes we were able to do just that. But when the funds ceased we found we had to replace them with permanent paid staff. The costs rose enormously, but so did our visitor numbers. However, the result of those 


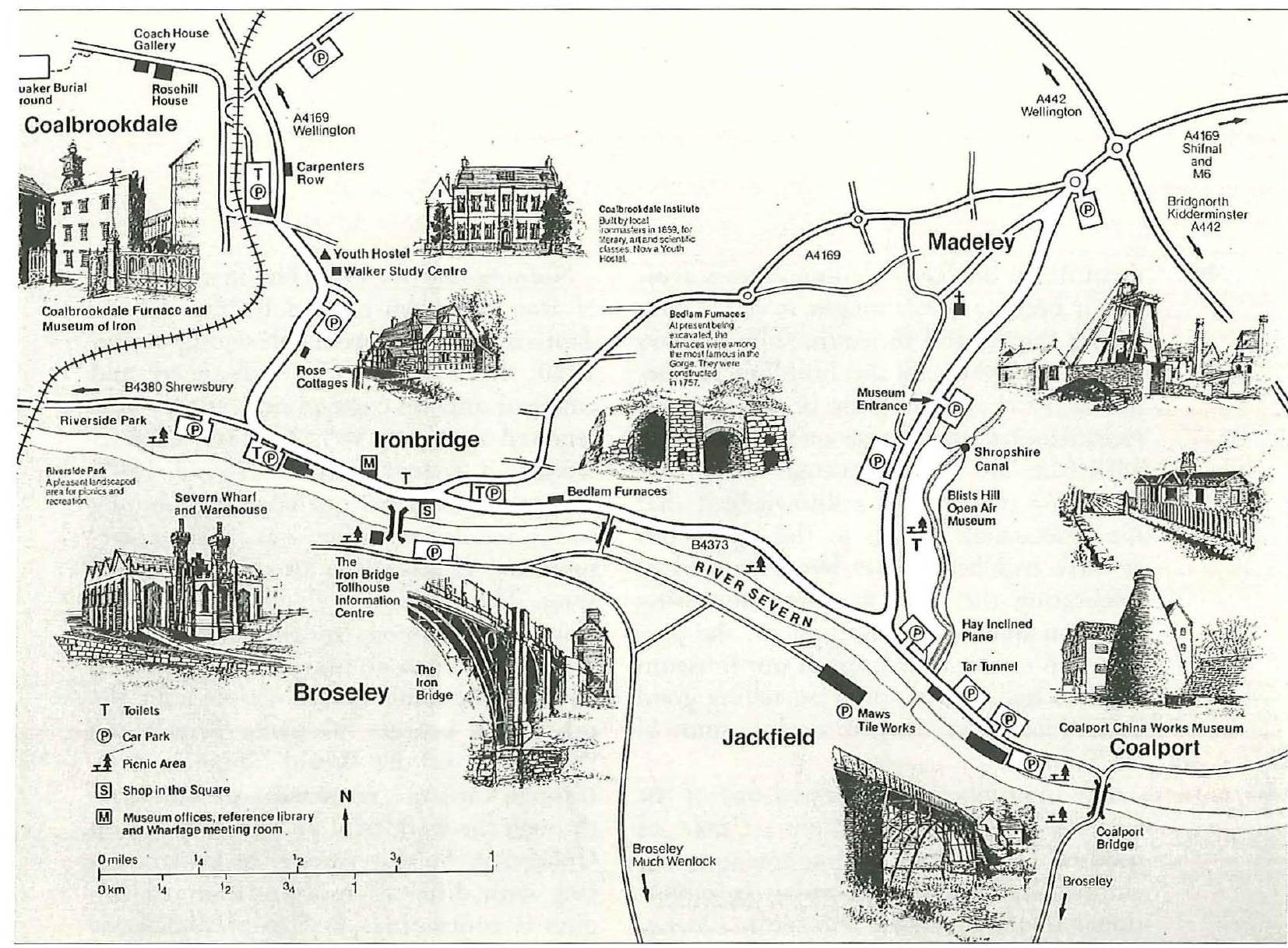

Ironbridge Gorge Museum med de ulike museumsanlegg, slik museet presenterte seg for publikum i 1983.

visitors seeing and enjoying a busy living museum at Blists Hill caused negative comments by those going on to the China Museum, the Severn Warehouse or the Museum of Iron. These, by contrast, were perceived as static and boring. But we decided to resist temptation of using demonstrators everywhere. For a start it was too expensive. Instead, we took the view that each museum should be different.

The China Museum which opened in 1976 had originally been called the 'Coalport China Works Museum', with the consequence that visitors expected factory tours, and as a result were disappoin- ted. I argued for the name 'Works' to be dropped, which we did from 1984, and displays were altered to look at the social history of the area, not just the end product. Issues such as diseases peculiar to the pottery industry were explored, as were the wages of women compared to men in the 1880s.

The Severn Warehouse had opened in 1977 as a Visitor Centre, but its title was confusing. In the early 80 s the concept of factory warehouse shopping was developing, but while the name 'Severn Warehouse' perfectly described the original function of the building - a warehouse to store cast-iron products prior to ship- 
ment down the River - some visitors avoided it because they thought it was a shop selling carpets and furniture! The displays were rethought and the building re-opened in 1989 as a Museum of the River. It reconstructed the Gorge at its industrial peak (the late 1790s) through a dramatic $40 \mathrm{ft}$ long model, and acknowledged that the spectacular growth in the eighteenth century had been short lived. Instead of celebrating the past, we were discussing the consequences of the past on the present. Up to this time most of our museum displays had concentrated on telling good news. Now it was time to explore some of the failures.

The interpretation addressed one of the legacies of industrialization - that of industrial pollution, a phenomenon that continues to be an issue today. In educational terms it was an enormous success, fitting perfectly into the themes studied by 7-14 year olds under the National Curriculum. However, our trusty 'Social Class AB1' visitors felt they were being lectured at, and criticised the Museum for apparently following government propaganda in promoting privatization of the water companies. In graphic design terms, we had moved away from the one size type 'text book on the walls' and had introduced a heirarchy of sizes rather in the style of the Sunday colour supplements - a big title and its subtitle encapsulating the main theme, one main paragraph somewhat smaller, and detailed texts smaller still for those that wanted the facts. At the bottom of each panel was a box containing technical facts or case studies in a type size that suggested you should read them only if you really wanted to.
Nothing lasts for ever. The first Museum of Iron had been created by the descendants of the Coalbrookdale Company in 1959. In 1979 it was redesigned and enlarged and its current exhibitions were renewed again in 1995. The new displays recreate a factory tour of around 1800 , recognising that visitors have been coming to the area for centuries - as artists, entrepreneurs, philosophers or even industrial spies. The 1 st floor tells the purely local story of the famous Ironworks, while the 2nd floor looks at how their inventions and developments spread throughout the nineteenth century to make Britain the 'Workshop of the World'. This is done through artists' responses to industry, through the wonderful images in the Elton Collection. So this pattern of experimenting with different interpretation techniques is continuing. At Coalbrookdale we have also opened up the reserve collections of heavy machinery, giving a glimpse behind the scenes; we also encourage visitors to handle and identify curious objects or at least guess what they were used for.

Blists Hill will not change for the foreseeable future and as the 1900 'turn of the century' moves further and further away, its educational value grows. It was the period that marks the watershed between small industries, crafts and trades and the growing industrial giants of the twentieth century. It is, after all, the era when the telephone and the motor car were new. Today our visitors are encouraged to step back in time. In the Victorian town there are no labels. Costumed demonstrators use 3rd person interpretation: «it was like that then, compared to what it is like today". Occasionally we do street theatre using first person interpretation - people 
pretending to be characters of the time, but mostly in pairs or small groups interacting with each other while the visitor remains a spectator. I hate the use of actors who intrude into the visitor's space. I am embarrassed by them and want to get away. For me they spoil a visit. But we use other interpretation devices to evoke the period of around 1900 - for instance, all prices are marked in England's curious pre-decimal money, and the first building you come to is a bank where you can exchange modern cash for old coinage, which can be used to buy goods such as beer, or bread, or candles at the original price. We do accept modern money, but it's not so much fun.

This year we are experimenting with a new layer of interpretation at Blists Hill. The site has many original industrial monuments on it - derelict blast furnaces, brickworks, a canal and inclined plane. These are being recognised as industrial archaeology and will be explained through graphic panels to help visitors understand what they are looking at. The process is experimental and will be evaluated, but we believe today's visitors are sophisticated enough to recognise the reconstructed town from the original industrial monuments.

\section{THE CONSEQUENCES OF OUTSIDE INFLUENCES}

At the outset in 1976 we believed that our daily running costs could be borne by the visitor rather than the State, and that development costs could come from industry and educational trusts. In practice, this has proved substantially correct, though outside influences beyond our control have had varying consequences.

It is widely accepted that Ironbridge was the scene of a whole series of technological breakthroughs in the eighteenth century which set the Industrial Revolution in progress. The moment one lists them the first manufacture of cheap iron, the first iron wheels, iron rails and railway locomotive, the first cast-iron bridge, the first iron-framed factory building - it is obvious that industry as it stood in the 1960s owed a lot to these inventions, particularly in engineering, transport and building. So it was relatively easy in the early days to go to those industries and ask for financial support. But economic cycles bring periods of recession as well as growth, and it was far harder to find money from industry in the late 1980 s and early 1990s. Instead we turned increasingly to educational trusts and European tourism development funds.

If we had set out to be an Ecomuseum, we would have targeted all our efforts at the local population, but the English are unhappy about being seen as part of a museum. They prefer a certain distance. While the natural beauty and amenity of the Gorge is a major asset, around half the visitors to the valley never come into the museums. It is an ecomuseum in the sense of a place to explore on many levels, to enjoy the pattern of historic buildings in a dramatic wooded environment, and it is one well used by the entire Midlands region. But they do not give much money towards supporting the restored heritage until they step into a museum. True, there is economic benefit from the local cafés, restaurants and petrol stations, but that does not pay our wages in the museum. As a result, we actively encourage visitors 
46 from the area with regional press and marketing, but a high proportion of visitors come from much further away. The Museum has become a national attraction, not purely a regional one. Fortunately, this had brought some indirect national funds.

The idea for the Museum originated with the Development Corporation of the New Town and they provided massive support for the first 15 years by restoring buildings and providing infrastructure, parking, etc. But all New Town Corporations have to hand over to local government after about 21 years - the situation which arrived in 1991. By that time the Museum Trust occupied several buildings and sites which actually belonged to the New Town. We had raised the money to equip them as museums and provide the interpretation, but we did not own the properties.

It was recognised long before 1986 that the Gorge had national and even international status in conservation and interpretation of our industrial heritage, and that this might be threatened by the transfer of properties out of our care. So the Department of Environment in London were persuaded to hand the properties over to the Museum, and with them a $£ 3$ million endowment, the interest from which would support the core activities of maintenance and conservation for which the Trust had been established. That endowment interest now provides about $15 \%$ of our running costs. The problem is that it was calculated at a time when inflation was running at nearly $10 \%$. Since then we have had five years of inflation of $4 \%$ or below, and the endowment earns proportionally less interest.

What other outside factors affect us?
Terrorism, petrol prices $(96 \%$ of our visitors come by car or coach), unemployment, the weather - all of them totally outside our control. The Gulf War brought a temporary halt to all American tourists. Recession increased the number of unemployed and caused many people to do without their traditional summer holiday. The very hot summer of 1995 meant that most visitors could not face being out of doors in an open air museum and it was not until the cool of the autumn that the visitor figures began to recover.

Government policy on employment from the late 70 s to the mid 80 s encouraged Work Experience schemes. We benefited enormously, and in 1980 we had 260 extra people to work alongside our 70 permanent staff. They erected buildings at Blists Hill and staffed them in period costume. They catalogued and conserved the collections, and supported every facet of our work. Reinforcing local identity, many people in the area have at some time or other worked at the Museum, but those on 6 or 12 month schemes found it hard to be motivated and to develop any loyalty. But when the schemes closed down, we found we had to take about 40 of these workers on full time because we had allowed them to do key tasks vital to our existence.

Apart from one year (1988) when excellent TV coverage brought a $48 \%$ increase in numbers, the Museum never makes any meaningful profit which could allow it to relax its charging policy. The local population resent having to pay admission for what they perceive as already having been paid for by taxes. In fact only a part has been funded this way (the original restoration of the buildings), but myths are very 
hard to destroy. Nevertheless, we are exploring an idea I have been proposing for some time - that all 130,000 of our local residents should be allowed in free of charge in exchange for a percentage of revenue funding from the local government (all we get from them at the moment is $1 \%$ of our running costs. There is fear of this within our Trustees because it brings with it a degree of political dependence which we have always avoided. But the advantage to the local community would be great, and I have no doubt that the increased pride it would generate would also translate into enough extra business in souvenir sales and catering to offset an added expense in cleaning and maintenance caused by higher numbers.

There is one more outside influence worth exploring - that of fashion. Undoubtedly the work of the Museum fits well with the 1980 s preoccupation with 'heritage'. 1975 to 1988 were almost continuous years of growth in visitor numbers. Since then the figures have remained largely static or slightly fallen to around 300,000 a year. Is this a natural business cycle? Or the signs of a fading interest in heritage? Is the television to blame where brilliant historic dramas seem more real than any museum experience? Ironbridge is looking to counteract this apparent fading interest by investing money and effort into interpreting the monuments throughout the area, most of which are outside pay boundaries of museums. We are also developing cycle paths and walks coupled with cycle hire to encourage 'green' tourism and extend the length of stay in the area. We are building a second studybedroom Youth Hostel to provide accom- modation at the lower end of the market, and we are exploring the concept of the 'museum without walls' through interactive computer technology.

The strategy of the Trust since 1992 has been 3-pronged:

- to provide an excellent day out;

- to invite appreciation of the Cradle of Industry;

- and to encourage longer stay visits through study and participation.

Any one of these could be affected by outside influences, but hopefully not all three at the same time.

\section{THE ROLE OF INNOVATION AND CHANGE}

Our fundamental belief has always been that Ironbridge's museums are for visitors - today and in the future. This sets us apart from the Ecomuseum at the outset. Aspects such as traditional research behind closed doors take second place to the expectation and needs of visitors. To maintain economic viability means that the Trust must continually do market research and look to innovation and change. We have carried out visitor surveys from the early years and have used the results to target advertising, educational material and improve visitor facilities. We have seen visitor numbers from London grow despite it being over three hours' drive away, and we encouraged this by advertising on the London underground, on a national classical radio frequency as well as in national papers.

Our surveys confirm the increasing proportion of the population who are over 50 but who have time and money to enjoy 
DAVID DE HAAN

themselves. As a result we have reviewed and improved our facilities for visitors with disabilities, whether they wear glasses (by increasing the type size in museum labels), wear a hearing aid (by installing induction loops) or have mobility problems (by installing ramps and extra seating). Our approach is entirely holistic. A ramp that is good for a wheelchair user is also good for a parent pushing a baby buggy. To help people round the Open Air Museum we are having a 1904-style charabanc built based on electric vehicles made in the area at that time.

As with any young company, our structure has undergone many changes. We were the first museum to set up a commercial trading arm designed to take advantage of tax laws. Today all museums recognise that shopping is a major element in the pursuit of leisure, but Ironbridge opened its first shop back in 1973. Under our first Director, Neil Cossons, trading developed into a significant provider of funds, and the selection of merchandise was under the control of the Curator and seen as subsidiary to his curatorial role. The Trading Company was altered as early as 1978 to take advantage of tax laws which allowed it to covenant profits back to the Museum. Ten years later the structure was altered again by creating a new General Manager of Trading of equal status to the Director. The result was good for a while, but what was being sold in the shops (we had 14 at one stage) was not always relevant to the Museum. To pull it all together again the Museum was unified under a Chief Executive in 1991 and subsequently both the Director and the General Manager posts were made redundant. The moral is that the structure that might be right at one period is not necessarily right 5 or 10 years later, and museums like any business should be prepared to move on. We are currently reviewing the overlapping roles of all our sister trusts to see if there is a better model for the late 1990s.

Neil Cossons was forever travelling the world lecturing and acting as ambassador to the Museum, and bringing back a whole string of ideas - many of them 'what not to do', but equally some of them along more positive lines. Costumed demonstrators and high quality design are two ideas that stem from this era. $\mathrm{He}$ also brought fundraising to an art form by developing a team that could convert money into finished projects on time and within budget. This brought a very high credibility rating and encouraged great loyalty from our industrial supporters, who inevitably had controlling interests in other companies that we invited to help. Unfortunately, when he moved on he took his fundraising skills with him and we now compete for funds with an evergrowing group of people.

In the 1970 s our fundraising wing (a sister trust) was most effective by having good personal contacts in industry; today a higher proportion of our funds come from European grants and it is necessary to know how to speak to the bureaucrats in Brussels. The Chief Executive's role today is almost exclusively bound up with fundraising and managing development projects. This ever-changing structure is characteristic of rapid growth. The challenge comes under the second phase - the established museum where visitor numbers settle, with the occasional peaks caused by advertising, special events or new 
projects and their attendant publicity. It is into this phase that we are gradually arriving and which is causing the most thinking.

\section{WORLD HERITAGE SITE}

Ironbridge has been a World Heritage Site since November 1986, which recognises it should "be preserved for all time for the benefit of mankind». This paper concludes with a look at the current thinking about what will be required over the next 30 years to maintain that status.

Having identified that the valley was important in the early 1960s, it was made a Conservation Area in 1967, and the historic sites had been identified and gradually conserved over the next two decades to restore the unique character of this remarkable area. It was a partnership between many groups, and between them they raised the area out of its dereliction. The wooded slopes had been acquired so that the valley could not be destroyed by any major building programme; the industrial monuments were restored and interpreted to a standard which has won the Museum virtually every award possible. So it was no great surprise that when the Gorge was submitted to UNESCO for inclusion in the World Heritage Site list that it was approved. Most World Heritage Sites are either natural, for example the Grand Canyon, or man-made, such as the Pyramids. Ironbridge is recognised in both categories and was the first industrial site on the list.

In 1987 the government recognised the importance of the area and the work of the Museum by announcing an endowment, initially at $£ 2$ million but subse- quently raised to $£ 3$ million, plus $£ 1$ mil49 lion more for immediate conservation work. With careful investment and the use of matching European and English Heritage funds, we have just completed a $£ 3.4$ million restoration programme to put the buildings and monuments into good repair. The interest from the endowment will pay towards future costs to keep them up to standard.

As early as 1978 an inter-disciplinary group met regularly to co-ordinate the work of the many agencies involved in the Gorge (the Development Corporation, the County Council, the Museum, etc) and this continues to this day, now encompassing even more representatives, including the trust owning the woodlands, English Heritage, the two District Councils, and the Environment Agency (responsible for the River). It met for a long time under a 'gentleman's agreement' and tried to spread the meagre funds to the best effect, but in 1995 the Inter-Agency Group got a new set of teeth. A powerful Strategy Group was formed with the Chairmen and Chief Executives of each Agency - in effect the holders of the purse strings - to coordinate bidding for funds. They only meet three times a year, but there are seven Task Groups who meet more regularly to carry out detailed work. Their areas of responsibility are: Historic Environment; Natural Environment; Database; Transport Infrastructure and Maintenance; Economic Development and Bidding; Public Consultation and Education; and Long Term Aspirations.

In this last group, we are looking at the elements which made the place so special and the threats that may destroy it - for example unsuitable planning develop- 
50 ment, too many tourists or even too few tourists, land stability, drainage, pollution, employment shifts, demographic changes, etc. A computerised database is being developed which will allow us to overlay each of these elements and decide how to allocate resources. Much of the data will be on public access as part of the 'museum without walls' initiative.

The hardest part of the Long Term Aspirations Task Group work has been to forecast what the pressures might be in the future, and we are starting with a target of what we want the Gorge to be like in 30 years time. Based on past surveys, we have been looking at the pattern of visitors to the area and testing out various scenarios. We are discussing whether the area should be pedestrianised, whether visitors can continue to be allowed to move about the area in their own cars, or whether they will have to use an integrated public transport system. For example, one scenario suggests that by 2025 only park \& ride buses, taxis, delivery vehicles and residents' cars will be allowed in the area. This would mean creating large reception centres on the outer edge of the Gorge where visitors can leave their cars and catch the shuttle buses, monorails, cable cars and steam trains!

This visionary approach is fraught with difficulties. Predicting the future is notoriously difficult. If one takes the visitor figures to the Museums from 1980-88, the statistics suggested the 400,000 peak in 1988 would rise to 500,000 by 1990 , to 650,000 by 1994 and to 850,000 by the year 2000 . The same visitor surveys identified that for every visitor who was counted entering a museum, there was another enjoying the valley. So the numbers have to be doubled. The transport consultants in 1988 said that by 1994 we would have to have a system of closing the valley at a fixed capacity to stop the visitors destroying the area. They were wrong of course. So after 29 years of evolution, the pioneering Ironbridge Gorge Museum has blossomed into a key element of a World Heritage Site. Its aspirations always were grand and its potential as a national asset predicted and achieved. But the mantle of Ecomuseum sits unhappily on English shoulders and has never been adopted. While the local residents are important, the history that surrounds them changed the world, so we see ourselves as more extrovert than an Ecomuseum, more varied than an open air museum and more interesting than a regional museum.

\section{NOTE}

The paper was read in the seminar From Burgundy to Bergslagen in honour of Ulla Keding Olofsson at Riksutställningar, Stockholm, May 301996.

\section{David de Haan är samlingsansvarig chef('Head of} Collections') vid Ironbridge Gorge-museet.

Adr: Ironbridge Gorge Museum Trust, Ironbridge,

Telford, Shropshire TF8 7AW, England.

$F A X+44-1952-432204$. 